\title{
Development of spotted wing drosophila in fruits of two raspberry cultivars
}

\author{
Razvoj octene mušice ploda u plodovima dvije sorte maline \\ Ivana Pajač Živković, Dana Čirjak, A. Mešić, B. Duralija, Darija Lemić
}

\begin{abstract}
Spotted wing drosophila (Drosophila suzukii (Matsumura, 1931)) a polyphagous alien invasive species causes economic damages in cultivation of soft fruits all over the word. It is widespread in Croatia and considering that the economic damage occurred in greenhouse cultivation of soft fruit several years ago, new damage in this production can be expected. The pest development was monitored on 50 overripe fruits of cultivars 'Amira' and 'Sugana' cultivated in greenhouses in Zagreb in 2018 to investigate pest preference for these cultivars and to make a risk assessment in raspberry cultivation. Pest presence was recorded on both cultivars at the same time, and D. suzukii was dominant drosophilid species in development. Significantly more drosophilids as well as individuals of $D$. suzukii were developed on cultivar 'Amira'. On 'Amira' 373 female and 211 male of D. suzukii developed, while on 'Sugana' 253 female and 142 males developed. Average number of pests per fruit on 'Amira' counted 11.68 and on 'Sugana' 7.9. Drosophila suzukii develops in high populations in the greenhouse production of raspberry cultivars, which poses a serious risk for their cultivation in the study site.
\end{abstract}

Key words: Drosophila suzukii, Drosophilidae, economic damages, Rubus idaeus, cultivar preference

\section{SAŽETAK}

Octena mušica ploda (Drosophila suzukii (Matsumura, 1931)) polifagna je strana invazivna vrsta koja uzrokuje ekonomske štete u uzgoju jagodastog voća diljem svijeta. Štetnik je rasprostranjen u Hrvatskoj i s obzirom da su ekonomske štete u plasteničkoj proizvodnji jagodastog voća zabilježene prije nekoliko godina, mogu se očekivati nove štete u uzgoju bobičastog voća. Razvoj štetnika praćen je na 50 prezrelih plodova sorata 'Amira' i 'Sugana' uzgajanih u plastenicima tijekom 2018. godine u Zagrebu. Cilj istraživanja bio je utvrditi sortnu preferenciju štetnika kako bi se procijenio rizik od njegove pojave u uzgoju maline. Prisutnost štetnika zabilježena je na obje sorte $u$ isto vrijeme, a vrsta $D$. suzukii bila je dominantna octena muha u uzorkovanim plodovima. Značajno više octenih muha i vrste $D$. suzukii razvilo se na sorti 'Amira'. Na sorti 
Ivana Pajač Živković i sur.: Development of spotted wing drosophila in fruits of two raspberry cultivars

'Amira' ukupno se razvilo 373 primjeraka ženki i 211 primjeraka mužjaka vrste $D$. suzukii, dok se na sorti 'Sugana' razvilo 253 primjeraka ženki i 142 primjerka mužjaka. Prosječan broj štetnika po plodu maline na sorti 'Amira' iznosio je 11.68, a na sorti 'Sugana' 7.9. Vrsta D. suzukii razvija se u visokim populacijama u plasteničkom uzgoju maline te predstavlja ozbiljnu opasnost za uzgoj maline na području istraživanja.

Ključne riječi: Drosophila suzukii, Drosophilidae, ekonomske štete, Rubus idaeus, sortna preferencija

\section{INTRODUCTION}

Spotted wing drosophila (Drosophila suzukii Matsumura) appeared in late 2000s in the European and American agroecological systems and became the major invasive pest (Asplen et al., 2015). It is native to Asia and its earliest records originate from 1916 in Japan (Kanzawa 1936. cit. Hauser et al., 2009). The species was first identified in Europe in 2008 in Spain (Calabria et al., 2010) and Italy (Cini et al., 2014), while it appeared in Croatia in 2010 (Masten Milek et al., 2011). Since then the pest spread rapidly throughout the whole country (Masten Milek et al., 2015) and became the dominant species in some agroecological systems (Pajač Živković et al., 2017).

Today, D. suzukii is found in all European countries (Cini et al., 2012, Dos Santos et al., 2017) and its rapid spread poses a challenge for scientists worldwide and requires constant studies of its biology, ecology and host preferences in order to develop and implement a long-term protection program based on environmentally friendly and sustainable protection (Bjeliš et al., 2015).

The nutrition of this pest is based mainly on fruits (Mitsui et al., 2010). Unlike other species of drosophilids, D. suzukii can damage fruits in the ripening stage or just before the harvesting (Lee et al., 2012). Especially, this pest prefers ripening fruit, more than overripe ones (Mitsui et al., 2006). It has been found on the fruits most during the color change phase (Lee et al., 2011). Females prefer to lay eggs inside the fresh and soft fruit, which represents direct damage and makes the fruit unmarketable (Bolda et al., 2010). The affected fruits can be identified by a small scar on the epidermis, which represents a stab wound, and by recessed soft dots that change color (Pajač and Barić 2010). Damage is also caused by one or more larvae feeding inside the fruit. Very rapidly, infested fruit begin to deteriorate around the feeding area (OEPP/EPPO 2010). The affected fruits are susceptible to attack by other drosophilids and secondary pathogens which represents indirect damage (Walsh et al., 2011, Pajač Živković et al., 2019). All these characteristics make this fly a serious 
threat for agriculture on global level (Hauser et al., 2009, Goodhue et al., 2011, De Ros et al., 2015). It attacks a wide host range, with preference for thin soft skinned fruits (Lee et al 2016). A study (Olazcuaga et al., 2019) showed that oviposition preference under choice conditions is strongly influenced by fruit phosphorus content and in general, raspberry, blackberry, and strawberry are among the best hosts while blackcurrant, grape and rose hips are poor hosts. Except for cultivated plants, it also develops on non-cultivated plants which serve them as alternative hosts on which pest feeds to survive adverse conditions (Klick et al., 2016). Due to its polyphagy, this species finds alternative hosts throughout the year, in natural and urbanized systems (Poyet et al., 2015).

Economic damages caused by this pest include yield losses, increased costs of labor and chemical suppression. There are problems with storage, but also with a shorter shelf life of fruits contaminated with pest eggs (Lee et al., 2012). Zero tolerance to this pest has led to the use of large amounts of insecticides, which caused high costs, but also problems in the sustainability and control of other pests (Leach et al., 2018). Current management relies on chemical control, which has raised concerns over the sustainability of this method (Jaffe and Guedot 2019).

To reduce economic damages and to sustain integrated pest management, it is very important to understand the population dynamics of D. suzukii (Burrack et al., 2015). The information on the time of the highest appearance of this pest in different hosts is the basis for making decisions on its management (Wollman et al., 2019). Effective control of this pest during vegetation is an extremely difficult task, due to its wide host range and high reproductive potential (Zerulla et al., 2015), so it is highly advisable to monitor the invasiveness of this species.

The first economic damages made by spotted wing drosophila in Croatia were detected in commercial production of fresh strawberries in 2016 (Pajač Živković et al., 2019). Except on strawberries, this species is a potentially important pest on other berries like raspberries. To date, the presence of this pest in Croatia has been reported in the cultivation of raspberries in the Istrian region (Masten Milek et al., 2015), but no economic damage to production was observed. The aim of this study was to determine the development of spotted wing drosophila on two varieties of raspberry ('Amira' and 'Sugana') in order to assess the risk of its occurrence and to take adequate protection measures in raspberry cultivation. 
Ivana Pajač Živković i sur.: Development of spotted wing drosophila

in fruits of two raspberry cultivars

\section{MATERIALS AND METHODS}

Experiment location

Research was conducted during 2018 in raspberry plantations located at Kupinečki Kraljevec $\left(45^{\circ} 40^{\prime} 58.8^{\prime \prime} \mathrm{N}, 15^{\circ} 51^{\prime} 0^{\prime \prime} \mathrm{E}\right)$ situated near the capital of Croatia Zagreb. The greenhouse plantations, where research was conducted, were raised in 2017 and raspberries are grown in the soilless system. Seedlings are planted in suitable pots, two plants per pot. The length of the row in the greenhouses was $40 \mathrm{~m}$, the distance between the rows was $1 \mathrm{~m}$ and in the row $0.5 \mathrm{~m}$.

Setting up the experiment

Research on development of D. suzukii was done on fruit samples of two primocane raspberry cultivars, 'Amira' and 'Sugana'. Each cultivar was grown in a separate greenhouse adjacent to each other. From each cultivar, 50 overripe raspberry fruits were collected on October 22, 2018. Sampled fruits were delivered the same day in portable refrigerator to entomological laboratory of the Department of Agricultural Zoology at the Faculty of Agriculture in Zagreb. The experiment was set in ten repetitions per cultivar, and each repetition contained five raspberry fruits. Raspberry fruits were placed in a $200 \mathrm{ml}$ plastic cup containing $2 \mathrm{~cm}$ of coarse vermiculite mineral, which was used to absorb moisture during the decomposition of the fruits. Each repetition with raspberry samples was then enclosed in a transparent plastic bag of 11 capacity, with 50 tiny holes drilled for ventilation. The prepared samples were placed in an airconditioning insect development chamber at an air temperature regime of $24{ }^{\circ} \mathrm{C}$ and a relative humidity of $60 \%$ according to a standardized procedure (Dean et al., 2013). Samples were examined on a weekly basis to determine the pest abundance and the experiment lasted until November 6, 2018. All fruit flies (fam. Drosophilidae) that developed from the fruits at each examination were narcotized with ether and stored in $70 \%$ alcohol until determination.

Determination of samples and data analyses

Diagnostic protocol OEPP/EPPO PM 7/115 for species (1) D. suzukii (OEPP/EPPO 2013) was used for species identification. The population abundance of developed drosophilids and species D. suzukii on both raspberry cultivars were subjected to analysis of variance (ANOVA) to determine the difference in the abundance number related to raspberry cultivars. A post-hoc means test was used when significant differences were found (Tukey's HSD). Statistical data processing (ANOVA, Tukey's HSD test) was performed using 
ARM 2019® GDM software (Gylling Data Management, Inc., Brookings, SD, USA) (Gylling Data Management Inc. 2019).

\section{RESULTS AND DISCUSSION}

The first specimens of vinegar flies (fam. Drosophilidae) were recorded on both raspberry cultivars the week after setting up the experiment (on October 29, 2018), and their development lasted until November 6, 2018, when the last specimens of this family were recorded. The presence of vinegar flies has been recorded in all repetitions. Table 1 shows total abundance of vinegar flies in both raspberry cultivars on each repetition of the experiment. Significantly higher number of vinegar flies was recorded on cultivar 'Amira' except in repetitions seven, eight and ten where significantly more vinegar flies developed on cultivar 'Sugana'. A total of 711 vinegar flies (fam. Drosophilidae) developed on the 'Amira' cultivar, and after determination 584 specimens (82\%) were found to belong to the species $D$. suzukii (Table 2). Their abundance ranged from 45 to 120 individuals per repetition (Table 2), which averages nine to 24 individuals per raspberry fruit. Development of spotted wing drosophila was also recorded in all repetitions (Table 2). Their numbers ranged from 32 to 112 individuals per repetition which averages 6.4 to 22.4 individuals per raspberry fruit.

Table 1 Abundance of vinegar flies (fam. Drosophilidae) on two different raspberry cultivars

Tablica 1. Brojnost octenih muha (por. Drosophilidae) na dvije sorte maline

\begin{tabular}{|l|c|c|c|c|c|c|c|c|c|c|c|}
\hline \multicolumn{1}{|c|}{ Repetitions } & I & II & III & IV & V & VI & VII & VIII & IX & X & $\sum$ \\
\hline 'Amira' & $89 \mathrm{a}^{*}$ & $120 \mathrm{a}$ & $77 \mathrm{a}$ & $96 \mathrm{a}$ & $72 \mathrm{a}$ & $46 \mathrm{a}$ & $45 \mathrm{~b}$ & $50 \mathrm{~b}$ & $66 \mathrm{a}$ & $50 \mathrm{~b}$ & $711 \mathrm{a}$ \\
\hline 'Sugana' & $41 \mathrm{~b}$ & $35 \mathrm{~b}$ & $29 \mathrm{~b}$ & $34 \mathrm{~b}$ & $36 \mathrm{~b}$ & $56 \mathrm{~b}$ & $70 \mathrm{a}$ & $71 \mathrm{a}$ & $65 \mathrm{~b}$ & $74 \mathrm{a}$ & $511 \mathrm{~b}$ \\
\hline
\end{tabular}

* Values of the same column followed by the same letter are not significantly different ( $\mathrm{p} \geq 0.05$; HSD test).

Table 2 Abundance of vinegar flies (fam. Drosophilidae) and species D. suzukii on cultivar 'Amira'

Tablica 2. Brojnost octenih muha (por. Drosophilidae) i vrste $D$. suzukii na sorti 'Amira'

\begin{tabular}{|l|c|c|c|c|c|c|c|c|c|c|c|}
\hline \multicolumn{1}{|c|}{ Repetitions } & I & II & III & IV & V & VI & VII & VIII & IX & X & $\sum$ \\
\hline Total Drosophilidae & 89 & 120 & 77 & 96 & 72 & 46 & 45 & 50 & 66 & 50 & $\mathbf{7 1 1}$ \\
\hline D. suzukii & 79 & 112 & 66 & 76 & 54 & 32 & 37 & 34 & 51 & 43 & $\mathbf{5 8 4}$ \\
\hline
\end{tabular}


A total of 511 individuals of drosophilids developed on cultivar 'Sugana', and 395 individuals (77\%) belonged to the D. suzukii species (Table 3). Vinegar flies also developed in all repetitions (Table 3), but their total abundance per repetition was slightly smaller than that of 'Amira' and ranged from 29 to 74 specimens per repetition which averages 6.8 to 14.8 individuals per raspberry fruit. The development of spotted wing drosophila was also recorded in all repetitions, ranging from 21 to 57 flies per repetition (Table 3), which averages 4.2 to 11.4 individuals per raspberry fruit. After statistical analyses it is obvious that significantly more $D$. suzukii developed on cultivar 'Amira', although the same number of significant repetitions was recorded on both cultivars in the experiment (Table 4).

Table 3 Abundance of vinegar flies (fam. Drosophilidae) and species D. suzukii on cultivar 'Sugana'.

Tablica. 3. Brojnost octenih muha (por. Drosophilidae) i vrste D. suzukii na sorti 'Sugana'

\begin{tabular}{|l|c|c|c|c|c|c|c|c|c|c|c|}
\hline \multicolumn{1}{|c|}{ Repetitions } & I & II & III & IV & V & VI & VII & VIII & IX & X & $\sum$ \\
\hline Total Drosophilidae & 41 & 35 & 29 & 34 & 36 & 56 & 70 & 71 & 65 & 74 & $\mathbf{5 1 1}$ \\
\hline D. suzukii & 21 & 32 & 27 & 26 & 25 & 47 & 51 & 54 & 55 & 57 & $\mathbf{3 9 5}$ \\
\hline
\end{tabular}

Table 4 Abundance of species $D$. suzukii on two different raspberry cultivars Tablica 4. Brojnost vrste $D$. suzukii na dvije različite sorte maline

\begin{tabular}{|l|c|c|c|c|c|c|c|c|c|c|c|}
\hline Repetitions & I & II & III & IV & V & VI & VII & VIII & IX & $\mathbf{X}$ & $\sum$ \\
\hline 'Amira' & $79 \mathrm{a}^{*}$ & $112 \mathrm{a}$ & $66 \mathrm{a}$ & $76 \mathrm{a}$ & $54 \mathrm{a}$ & $32 \mathrm{~b}$ & $37 \mathrm{~b}$ & $34 \mathrm{~b}$ & $51 \mathrm{~b}$ & $43 \mathrm{~b}$ & $584 \mathrm{a}$ \\
\hline 'Sugana' & $21 \mathrm{~b}$ & $32 \mathrm{~b}$ & $27 \mathrm{~b}$ & $26 \mathrm{~b}$ & $25 \mathrm{~b}$ & $47 \mathrm{a}$ & $51 \mathrm{a}$ & $54 \mathrm{a}$ & $55 \mathrm{a}$ & $57 \mathrm{a}$ & $395 \mathrm{~b}$ \\
\hline
\end{tabular}

* Values of the same column followed by the same letter are not significantly different ( $p \geq 0.05$; HSD test).

The development of drosophilid flies on raspberry has never been explored in Croatia so far, but the dominance of $D$. suzukii on some grapevine cultivars has been noted (Pajač Živković et al., 2017). The study was conducted in northern Croatia in Međimurje and showed that the invasive species D. suzukii became dominant in the study area. Similarly, this research of the development of spotted wing drosophila on different raspberry cultivars confirmed its dominance in another crop in Croatia. In Croatia the development of drosophilid species in the greenhouse production of strawberries was studied and although the presence of $D$. suzukii was confirmed, its dominance has not been established since the native drosophilid species $D$. simmulans develops mostly in strawberry (Pajač Živković et al., 2019). 
On the other hand, this research confirmed that D. suzukii, as an invasive species, opened the way to other drosophilid flies to became pests in raspberry cultivation area of Kupinečki Kraljevec. Furthermore, the presence of D. suzukii in raspberries grown outdoors has been established in Croatia (Masten Milek et al., 2015), but this study confirmed its dominance and development in a population that can cause economic damage in production. The development of spotted wing drosophila on the two cultivars was different. On cultivar 'Amira' 189 individuals of spotted wing drosophila developed more than on cultivar 'Sugana'. The average number of $D$. suzukii individuals per one raspberry fruit on the 'Amira' variety was 11.68 , and on the 'Sugana' variety 7.9. Although grown in the same position and under the same conditions, different number of adult drosophilid flies and D. suzukii species has been reported in the cultivars. Both varieties have excellent characteristics (high quality fruits of excellent shelf life) and have one parent ('Tulameen') in common (Kobelt 2009, Grisenti 2012). Despite all the good characteristics and similarities between these two, this study has confirmed that $D$. suzukii still prefers cultivar 'Amira' suggesting that the chemical composition of the fruit influences the pest oviposition preference (Olazcuaga et al., 2019).

A total of 373 females (64.5\%) and 211 males (35.5\%) of D. suzukii developed on the 'Amira' cultivar (Table 5). During the examination on October 30, a total of 242 females and 132 males were recorded. A smaller number of individuals developed from the samples examined on November 6, but the female population was still dominant. The number of females on the mentioned date of examination amounted to 131 and males 79 , and the overall dominance of females indicates a further increase in the pest population. The highest number of spotted wing drosophila was recorded in II repetition of 'Amira' cultivar, containing 112 individuals of this species (Table 2). At the same time, this repetition contained the highest number of females (63) but also the highest number of males (49) of D. suzukii species (Table 5).

Table 5 Number of males and females of species D. suzukii on cultivar 'Amira'

Tablica 5. Brojnost mužjaka i ženki vrste $D$. suzukii na sorti 'Amira'

\begin{tabular}{|l|c|c|c|c|c|c|c|c|c|c|c|}
\hline \multicolumn{1}{|c|}{ Repetitions } & I & II & III & IV & V & VI & VII & VIII & IX & X & $\sum$ \\
\hline Female (F) & 53 & 63 & 43 & 49 & 38 & 21 & 19 & 24 & 31 & 32 & $\mathbf{3 7 3}$ \\
\hline Male (M) & 26 & 49 & 23 & 27 & 16 & 11 & 18 & 10 & 20 & 11 & $\mathbf{2 1 1}$ \\
\hline F share (\%) & 67 & 56 & 65 & 64 & 70 & 66 & 51 & 71 & 61 & 74 & $\mathbf{6 4 . 5}$ \\
\hline M share (\%) & 33 & 44 & 35 & 36 & 30 & 34 & 49 & 29 & 39 & 26 & $\mathbf{3 5 . 5}$ \\
\hline
\end{tabular}


A total of 253 females (65\%) and 142 males (34\%) of the D. suzukii species developed on the 'Sugana' cultivar (Table 6). On October 30, 191 specimens of females and 101 specimens of males were determined, and on November 6, 62 specimens of females and 41 specimens of males, and these results indicate a similar population growth trend, which was also observed on cultivar 'Amira'.

Table 6 Number of males and females of species D. suzukii on cultivar 'Sugana'

Tablica 6. Brojnost mužjaka i ženki vrste $D$. suzukii na sorti 'Sugana'

\begin{tabular}{|l|c|c|c|c|c|c|c|c|c|c|c|}
\hline \multicolumn{1}{|c|}{ Repetitions } & I & II & III & IV & V & VI & VII & VIII & IX & X & $\sum$ \\
\hline Female (F) & 16 & 22 & 19 & 17 & 15 & 32 & 36 & 29 & 38 & 29 & $\mathbf{2 5 3}$ \\
\hline Male (M) & 5 & 10 & 8 & 9 & 10 & 15 & 15 & 25 & 17 & 28 & $\mathbf{1 4 2}$ \\
\hline F share (\%) & 76 & 69 & 70 & 65 & 60 & 68 & 71 & 54 & 69 & 51 & $\mathbf{6 5 . 3}$ \\
\hline M share (\%) & 24 & 31 & 30 & 35 & 40 & 32 & 29 & 46 & 31 & 49 & $\mathbf{3 4 . 7}$ \\
\hline
\end{tabular}

In both raspberry cultivars, female dominance was recorded, which implies that further population increase can be expected. From a biological point of view, female-dominated insect populations have better biological potential (Pajač Živković et al., 2019), which means that such populations will continue to grow and expand in the future. The results of of research confirmed the dominance of D. suzukii species in agroecological systems of fruit growing in greenhouses in Croatia, and its preference for raspberry cultivar 'Amira'. The conducted research is a contribution to the knowledge of the invasive character of the species, the great potential for the spread and development of this pest, and at the same time the harmfulness of the D. suzukii in greenhouse raspberry cultivation has been confirmed.

\section{CONCLUSIONS}

With this study the economic damages of $D$. suzukii to raspberry fruits of cultivars 'Amira' and 'Sugana' grown under greenhouse conditions have been determined. Spotted wing drosophila was the dominant species of drosophilid flies on both cultivars which opened the way to other drosophilid to become pests in greenhouse raspberry cultivation. Although the 'Amira' and 'Sugana' cultivars were grown in the same position and under the same conditions, the D. suzukii species was more represented in the 'Amira' cultivar. The average number of $D$. suzukii individuals per raspberry fruit on the 'Amira' cultivar was 11.68, and on the 'Sugana' cultivar 7.9. Despite many similarities between the 
compared cultivars, the pest still showed a preference for the 'Amira' cultivar suggesting that the chemical composition of the fruit influences the oviposition preference of the pest. Finally, a higher number of females $(>60 \%)$ than males $(<40 \%)$ was found in both cultivars, which is a good prerequisite for further expansion of the spotted wing drosophila population. Considering the dominance of the species in open-air agroecological systems and in greenhouses, in the future, economic losses in growing raspberries and other fruit species can be expected in Croatia.

\section{LITERATURE}

ASPLEN, M. K., ANFORA, G., BIONDI, A., CHOI, D., CHU, D., DAANE, K. M., GIBERT, P., GUTIERREZ,A. P., HOELMER, K. A., HUTCHISON, W. D., ISAACS, R., JIANG, Z., ZSOLT KÁRPÁTI, Z., KIMURA, M. T., PASCUAL, M., PHILIPS, C.R., PLANTAMP, C., PONTI, L., VÉTEK, G., VOGT, H., WALTON, V. M., YU Y., ZAPPALÀ, L., DESNEUX, N. (2015): Invasion biology of spotted wing Drosophila (Drosophila suzukii): a global perspective and future priorities. Journal of Pest Science. 88: 469-494. DOI: http://dx.doi.org/10.1007/s10340-015-0681-z

BJELIŠ, M., BULJUBAŠIĆ, I., POPOVIĆ, L., MASTEN MILEK, T. (2015): Spread of the spotted wing drosophila - Drosophila suzukii (Diptera, Drosophlidae) and new distribution records in Dalmatia region of Croatia. Bulletin OEPP/EPPO. 45 (2): 214-217.

DOI: https://doi.org/10.1111/epp.12205

BOLDA, M. P., GOODHUE, R. E., ZALOM, F. G. (2010): Spotted wing drosophila: potential economic impact of a newly established pest. Giannini Foundation of Agricultural Economics. University of California, 13, 5-8.

BURRACK, H. J., ASPLEN, M., BAHDER, L., COLLINS, J., DRUMMOND, F., GUE'DOT, C., ISAACS, R., JOHNSON, D., BLANTON, A., LEE, J. C., LOEB, G., RODRIGUEZ-SAONA, C., VAN TIMMEREN, S., WALSH, D., MCPHIE, D.R. (2015): Multistate comparison of attractants for monitoring Drosophila suzukii (Diptera: Drosophilidae) in blueberries and caneberries. Environmental Entomology. 44: 704-712.

DOI: https://doi.org/10.1093/ee/nvv022 
CALABRIA, G., MÁCA, J., BÄCHLI, G., SERRA, L., PASCUAL, M. (2012): First records of the potential pest species Drosophila suzukii (Diptera: Drosophilidae) in Europe. Journal of Applied Entomology. 136: 139-147. DOI: http://dx.doi.org/10.1111/j.1439-0418.2010.01583.x

CINI, A., IORIATTI, C., ANFORA, G. (2012): A review of the invasion of Drosophila suzukii in Europe and a draft research agenda for integrated pest management. Bulletin of Insectology. 65: 149-160.

CINI, A., ANFORA, G., ESCUDERO-COLOMAR, L. A., GRASSI, A., SANTOSUOSSO, U., SELJAK, G., PAPINI, A. (2014): Tracking the invasion of the alien fruit pest Drosophila suzukii in Europe. Journal of Pest Science. 87: 559-566. DOI: http://dx.doi.org/10.1007/s10340-014-0617-z

DE ROS, G., CONCIA, S., PANTEZZIA, T., SAVINIB, G. (2015): The economic impact of invasive pest Drosophila suzukii on berry production in the Province of Trento, Italy. Journal of Berry Research. 5: 89-96. DOI: http://dx.doi.org/10.3233/JBR-150092

DEAN, D., PRICE, J. F., STECK, G., NAGLE, C. A. (2013): Development and impact of the spotted wing Drosophila, Drosophila suzukii, in Florida strawberries. International Journal of Fruit Science. 13 (1-2): 67-75. DOI: http://dx.doi.org/10.1080/15538362.2012.696992

DOS SANTOS, L. A., MENDES, M. F., KRÜGER, A. P., BLAUTH, M. L., GOTTSCHALK, M. S., GARCIA, F. R. M. (2017) Global potential distribution of Drosophila suzukii (Diptera, Drosophilidae). PLoS ONE. 12 (3): 1-13. DOI: https://doi.org/10.1371/journal. pone.0174318

GOODHUE, R. E., BOLDA, M., FARNSWORTH, D., WILLIAMS, J. C., ZALOM, F. G. (2011) Spotted wing drosophila infestation of California strawberries and raspberries: economic analysis of potential revenue losses and control costs. Pest Management Science. 67: 1396-1402. DOI: https://doi.org/10.1002/ps.2259

GRISENTI, M. A. (2012): Variety of Rubus plant named 'BP1'. Plant patent Application Publication, US 2011/02771.94 P1 1-15.

GYLLING DATA MANAGEMENT INC. ARM 2019®GDM Software; Revision 2019.4; GYLLING DATA MANAGEMENT INC.: BROOKINGS, SD, USA, 2019. 
HAUSER, M., GAIMARI, S., DAMUS, M. (2009): Drosophila suzukii new to North America. Fly times. 43: 13-15.

JAFFE, B. D., GUÉDOT, C. (2019): Vertical and temporal distribution of spotted-wing drosophila (Drosophila suzukii) and pollinators within cultivated raspberries. University of Wisconsin-Madison. DOI: https://doi.org/10.1002/ps.5343

KLICK, J., YANG, W. Q., WALTON, V. M., DALTON, D. T., HAGLER, J. R., DREVES, A. J., LEE, J. C., BRUCK, D. J. (2016): Distribution and activity of Drosophila suzukii in cultivated raspberry and sur.rounding vegetation. Journal of Applied Entomology. 140: 37-46.

DOI: http://dx.doi.org/10.1111/jen.12234

KOBELT, M. (2009): Variety of Rubus plant named 'Sugana'. Plant patent Application Publication, US 2009/0282590 P11-16.

LEACH, H., MOSES, J., HANSON, E., FANNING, P., ISAACS, R. (2018): Rapid harvest schedules and fruit removal as non-chemical approaches for managing spotted wing drosophila. Journal of Pest Science. 91: 219-226. DOI: https://doi.org/10.1007/s10340-017-0873-9

LEE, J. C., BRUCK, D. J., DREVES, A. J., IORIATTI, C., VOGT, H., BAUFELDE, P. (2011): In Focus: Spotted wing drosophila, Drosophila suzukii, across perspectives. Pest Management Science. 67: 1349-1351. DOI: https://doi.org/10.1002/ps.2271

LEE, J. C., BRUCK, D. J., DREVES, A. J., IORIATTI, C., VOGT, H., BAUFELDE, P. (2012): The susceptibility of small fruits and cherries to the spotted-wing drosophila, Drosophila suzukii. Pest Management Science. 67: 1349-1351. DOI: http://dx.doi.org/10.1002/ps.2225

LEE, J. C., DALTON, D. T., SWOBODA-BHATTARAI, K. A., BRUCK, D. J., BURRACK, H. J., STRIK, B. C., WOLTZ, J. M., WALTON, V. M. (2016): Characterization and manipulation of fruit susceptibility to Drosophila suzukii. Journal of Pest Science. 89: 771-780.

DOI: https://doi.org/10.1007/s1034 0-015-0692-9

MASTEN MILEK, T., SELJAK, G., ŠIMALA, M., BJELIŠ, M. (2011): Prvi nalaz Drosophila suzukii (Matsumura, 1931) (Diptera: Drosophilidae) u Hrvatskoj. Glasilo biljne zaštite. 11 (5): 377-382. 
MASTEN MILEK, T., ŠIMALA, M., BJELIŠ, M. (2015): Octena mušica ploda (Drosophila suzukii) - štetnik plodova voća. Glasilo biljne zaštite. 15 (5): 323-327.

MITSUI, H., TAKAHASHI, H. K., KIMURA, M. T. (2006): Spatial distributions and clutch sizes of Drosophila species ovipositing on cherry fruits of different stages, Population Ecology. 48: 233-237.

DOI: https://doi.org/10.1007/s10144-006-0260-5

MITSUI, H., BEPPU, K., KIMURA, T. M. (2010): Seasonal life cycles and resource uses of flower- and fruit-feeding drosophilid flies (Diptera: Drosophilidae) in central Japan. Entomological Science. 13: 60-67. DOI: http://dx.doi.org/10.1111/j.1479-8298.2010.00372.x

OEPP/EPPO (2010): Report of a Pest Risk Analysis for Drosophila suzukii 11-17190.

OEPP/EPPO (2013): Drosophila suzukii. Bulletin OEPP/EPPO. 43 (3): 417- 424.

OLAZCUAGA, L., RODE, N. O., FOUCAUD, J., FACON, B., RAVIGNÉ, V., AUSSET, A., LEMÉNAGER, N., LOISEAU, A., GAUTIER, M., ESTOUP, A., HUFBAUER, R. A. (2019): Oviposition Preference and Larval Performance of Drosophila suzukii (Diptera: Drosophilidae), Spotted-Wing Drosophila: Effects of Fruit Identity and Composition. Environmental Entomology. 48 (4): 867-881. DOI: 10.1093/ee/nvz062

PAJAČ, I., BARIĆ, B. (2010): Drosophila suzukii (Matsumura, 1931) potencijalni štetnik koštićavog voća u Hrvatskoj. Pomologia Croatica. 16 (1-2): 43-50.

PAJAČ ŽIVKOVIĆ, I., BARIĆ, B., LEMIĆ, D., BLAŽEVIĆ, I., ŠUBIĆ, M., SELJAK, G., MEŠIĆ, A. (2017): The Drosophilid Fauna (Diptera, Drosophilidae) of IPM Vineyards in Croatia. Agriculturae Conspectus Scientificus. 81 (4): 231-234.

PAJAČ ŽIVKOVIĆ, I., DURALIJA, B., BARIĆ, B., SELJAK, G., LEMIĆ, D., MEŠIĆ, A. (2019): The development of drosophilid species (Diptera, Drosophilidae) in different strawberry cultivars. European Journal of Horticultural Science. 84 (1): 48-52.

DOI: https://doi.org/10.17660/eJHS.2019/84.1.7 
POYET, M., LE ROUX, V., GIBERT, P., MEIRLAND, A., PRÉVOST, G., ESLIN, P., CHABRERIE, O. (2015): The Wide Potential Trophic Niche of the Asiatic Fruit Fly Drosophila suzukii: The Key of Its Invasion Successin Temperate Europe? PloS ONE. 10 (11): 1-26.

DOI: http://dx.doi.org/10.1371/journal.pone.0142785

WALSH, D. B., BOLDA, M. P., GOODHUE, R. E., DREVES, A. J., LEE, J., BRUCK, D. J.,WALTON, V. M., O'NEAL, S. D., ZALOM, F. G. (2011): Drosophila suzukii (Diptera: Drosophilidae): Invasive Pest of Ripening Soft Fruit Expanding its Geographic Range and Damage Potential. Journal of Integrated Pest Management. 2 (1): 1-7.

DOI: http://dx.doi.org/10.1603/IPM10010

WOLLMANN, J., SCHLESENER, D. C. H., FERREIRA, M. S., KRUGER, A. P., BRNARDI, D., GARCIA, J. A. B., NUNES, A. M., GARCIA, M.S, GARCIA, F. R. M. (2019): Population Dynamics of Drosophila suzukii (Diptera: Drosophilidae) in Berry Crops in Southern Brazil. Neotropical Entomology. 48: 699-705. DOI: https://doi.org/10.1007/s13744-019-00686-5

ZERULLA, F. N., SCHMIDT, S., STREITBERGER, M., ZEBITZ, C. P. W., ZELGER, R. (2015): On the overwintering ability of Drosophila suzukii in South Tyrol. Journal of Berry Research. 5: 41-48.

\section{Authors address - Adresa autora:}

Ivana Pajač Živković, e-mail: ipajac@agr.hr,

Dana Čirjak, student of Undergraduate study Phytomedicine

Aleksandar Mešić,

Darija Lemić

University of Zagreb Faculty of Agriculture,

Department of Agricultural Zoology,

Svetošimunska cesta 25, 10000 Zagreb

Boris Duralija

University of Zagreb Faculty of Agriculture,

Department of Pomology,

Svetošimunska cesta 25, 10000 Zagreb 
Ivana Pajač Živković i sur.: Development of spotted wing drosophila in fruits of two raspberry cultivars 